ISSN: 1858-3385, EISSN: 2549-7006

GASTER Vol. 17 No. 2 Agustus 2019

\title{
Pengaruh Terapi Emotional Freedom Technique dalam Menurunkan Tekanan Darah pada Lansia Hipertensi
}

\author{
Atyanti Isworo $^{1 *}$, Akhyarul Anam ${ }^{1}$, Nur Indrawati ${ }^{2}$ \\ ${ }^{1}$ Jurusan Keperawatan Universitas Jenderal Soedirman, Purwokerto \\ ${ }^{2}$ Rumah Sakit Margono Soekarjo, Purwokerto \\ *E-mail: atyanti.isworo@gmail.com \\ Doi : https://doi.org/10.30787/gaster.v17i2.438 \\ Received: July 2019 | Revised: July 2019 | Accepted: Agustus 2019
}

\begin{abstract}
ABSTRAK
Kondisi stres akan meningkatkan pelepasan kortisol sehingga akan menyebabkan peningkatan tekanan darah. Terapi Emotional Freedom Technique (EFT) dipercaya mampu untuk menghilangkan emosi berlebihan seperti stres, Tujuan penelitian ini adalah untuk mengidentifikasi pengaruh terapi EFT terhadap penurunan tekanan darah pada lansia hipertensi. Penelitian ini menggunakan metode quasi experiment dengan pendekatan pretest-positest with control group design. Teknik pengambilan sampel menggunakan metode consecutive sampling, dengan kriteria inluksi (1) bersedia menjadi responden, (2) Tekanan Darah Sistolik (TDS) 140-160 mmHg dan Tekanan Darah Diastolik (TDD) 90-100 mmHg, (3) tidak menderita gagal ginjal, penyakit kardiovasuler lainnya, dan diabetes, (4) pasien yang mengkonsumi obat anti hipertensi. sedangkan kriteria eksklusi adalah (1) pasien yang tidak mengikuti semua tahapan terapi, (2) menggunakan obat atau teknik untuk menurunkan stres, (3) mengalami penurunan kesadaran, (4) mempunyai masalah pendengaran. Sebanyak 32 lansia hipertensi, dibagi menjadi dua kelompok, masing-masing 16 responden untuk kelompok intervensi dan kelompok kontrol. Terapi EFT dilakukan selama 20 menit setiap hari selama seminggu. Alat untuk mengukur tekanan darah menggunakan sphignomanometr air raksa manual, merk Sphymed Medical. Analisis data menggunakan Uji-T. Hasil penelitian menunjukkan ada perbedaan yang bermakna TDS sebelum dan setelah diberikan terapi EFT ( $<<0,001)$, tetapi tidak ada perbedaan yang bermakna pada TDD pada kelompok intervensi $(p=0,699)$. Pada kelompok kontrol baik TDS maupun TDD tidak ada perbedaan bermakna sebelum dan sesudah perlakuan $(p=0,343),(p=0,620)$, berurutan. Namun, ditemukan adanya perbedaan yang bermakna penurunan TDS antara kelompok intervensi dan kelompok kontrol ( $p=0,014)$, namun tidak demikian pada TDD $(p=0,582)$. Dapat disimpulkan bahwa EFT mampu menurunkan tekanan darah sistolik pada lansia hipertensi.
\end{abstract}

Kata kunci:Emotional freedom technique (EFT); hipertensi; lansia; tekanan darah

154 Pengaruh Terapi Emotional Freedom Technique .... 


\section{ABSTRACT}

Stressful conditions will increase the release of cortisol, it will increase in blood pressure. Emotional Freedom Technique (EFT) therapy is believed to be able to eliminate excessive emotions such as stress. The purposes of this study was to identify the effect of Emotional Freedom Technique (EFT) therapy on blodd pressure level of hypertension pastients. This study used a quasi-experimental with pretest-posttest with control group design. The sample was taken using consecutive sampling with the inclusion criteria are (1) willing to be respondents, (2) Systolic Blood Pressure (SBP) 140-160 mmHg and Diastolic Blood Pressure (DBP) 90-100 $\mathrm{mmHg}$, (3) not suffering from kidney failure, other cardiovascular disease and diabetes, (4) did not counsume antihypertensive drugs. While exclusion criteria are (1) do not follow all stages of EFT procedures, (2) uses drugs or techniques to reduce stress, (3) experiencing loss of consiousness and (4) having audio problmes. A total of 32 elderly hypertension, divided into two groups, each group 16 respondents for the intervention group and the control group. EFT therapy is carried out for 20 minutes everyday for seven days. Tool for measuring blood pressure using manual mercury Sphinomanometer "Sypymed Medical". Data analysis using the Paired T-test and Independent T-test. The results reveled there was significant differences in SBP before and after EFT therapy $(p<, 0.001)$, but there was no significant diffrence in DBP before and after EFT therapy $(p=0.699)$. In the control group both SBP and DBP there were no significant differences before and after treatment ( $p=0.343)$; $(p=0.620)$, respectively. However, there were a significant difference in the decrease in SBP between intervention group and the control group $(p=0.014)$, but no significant difference in the DBP $(p=0.582)$. It concluded that EFT therapy is able to reduce SBP in the elderly hypertension.

Keywords:Emotional freedom technique (EFT); hypertension; elderly; blood pressure

\section{PENDAHULUAN}

Hipertensi merupakan suatu keadaan terjadinya peningkatan tekanan darah yang mana dapat menyebabkan gejala berlanjut pada suatu target organ tubuh sehingga timbul kerusakan lebih berat seperti stroke ataupun penyakit jantung koroner.Penyakit ini masih menjadi masalah kesehatan dengan prevalensi yang tinggi (Kemenkes, 2014).
Depkes RI pada tahun 2013 telah melakukan beberapa langkah untuk mengendalikan hipertensi, yaitu mendistribusikan buku pedoman hipertensi, melaksanakan advokasi dan sosialisasi, melaksanakan intensifikasi, akselerasi, dan inovasi program sesuai dengan kemajuan teknologi dan kondisi daerah setempat, mengembangkan sumber daya manusia dalam pengendalian 3 hipertensi, memperkuat jaringan kerja pengendalian 
hipertensi, antara lain dengan dibentuknya kelompok kerja pengendalian hipertensi, memperkuat logistik dan distribusi untuk deteksi dini faktor resiko penyakit jantung dan pembuluh darah termasuk hipertensi, meningkatkan surveilans epidemiologi dan sistem informasi pengendalian hipertensi, melaksanakan monitoring dan evaluasi, dan mengembangkan sistem pembiayaan pengendalian hipertensi. Banyak upaya yang dilakukan oleh Pemerintah tetapi prevalensi kejadian hipertensi di Indonesia terus mengalami peningkatan.

Data Riskesdas tahun 2018 menunjukkan prevalensi hipertensi mengalami peningkatan jika dibandingkan dengan Riskesdas 2013, hipertensi naik dari 25,8\% menjadi 34,1\% (Riskesdas 2018). Data profil kesehatan Provinsi Jawa Tengah tahun 2017 tercatat prevalensi kasus hipertensi sebanyak 1.153.371 atau 12,98\%. Data Dinas Kesehatan Kabupaten Banyumas (2017) jumlah penderita hipertensi sebanyak 24.426 orang. Dari data tersebut, terdapat beberapa wilayah yang angka kejadian hipertensi cukup tinggi, salah satunya yaitu Kelurahan Purwokerto Utara dengan jumlah penderita hipertensi sebanyak 2814 orang. Dari jumlah tersebut, 715 kasus berusia $>60$ tahun.
Menurut Badan Pusat Statistik (2018), pada tahun 2018, persentase lansia Indonesia mencapai 9,27 persen atau sekitar 24, 49 juta orang. Persentase tersebut didominasi oleh lansia muda (kleompok umur 60-69 tahun) persentasenya mencapai 63,39 persen, lansia madya (kelompok umur 70-79 tahun) sebesar 27,92 persen dan sisanya ( 8,69 persen) adalah lansia tua (lebih dari 80 tahun).

Hipertensi umumnya terjadi pada lansia. Berdasarkan laporan rumah sakit melalui Sistem Informasi Rumah Sakit (SIRS) tahun 2010, hipertensi esensial menjadi sepuluh peringkat terbesar penyakit penyebab rawat jalan pada kelompok lansia atau usia 45-64 tahun dan usia diatas 65 tahun (Kemenkes RI, 2014). Penyebab hipertensi pada lansia karena semakin bertambahnya usia maka fungsi fisiologis semakin mengalami penurunan akibat proses degeneratif (penuaan). Lansia akan mengalami degenerasi pada sistem kardiovaskular seperti kekakuan dan penebalan katup jantung, penurunan elastisitas dinding aorta, penurunan fungsi jantung $1 \%$ setiap tahun sehingga menyebabkan penurunan kontraksi dan curah jantung. Hal ini yang bisa menyebabkan hipertensi (Potter \& Perry 2012). Selain itu, faktor risiko hipertensi 
salah satunya adalah stres. Penelitian yang dilakukan oleh Seke, Bidjuni \& Lolong (2016) menyebutkan ada hubungan antara kejadian stres dengan hipertensi pada lansia.

Kondisi stres akan meningkatkan pelepasan hormon kortisol dan pelepasan hormon di kelenjar feokromositoma. Pelepasan hormon tersebut pada akhirnya menyebabkan peningkatan kadar hormon steroid dalam darah. Selanjutnya peningkatan kadar hormon steroid akan menyebabkan produksi adrenalin yang berlebihan sehingga epinefrin meningkat. Hormon inilah yang menyebabkan denyut jantung dan tekanan darah meningkat (hipertensi) (Rokade, 2011).

Saat stres, terjadi peningkatan aktivitas saraf simpatis. Hal ini dapat memicu terjadinya peningkatan tekanan darah secara intermitten (tidak menentu). Sehingga hormon endorfin terganggu sedangkan hormon endrofin tersebut berfungsi sebagai pengatur respon tehadap stres (Yaribeygi, Panahi, Sahrei, Johnston, Sahebkar, 2017).

Menurut Iskandar (2010), EFT adalah alat terapi psikologi yang dapat digunakan untuk menghilangkan emosi yang berlebihan dan bersifat negatif, seperti perasaan kesal, sedih dan stres. Ilmuan lain mendefinisikan
EFT sebagai sebuah metode yang brilian namun sederhana untuk meredakan rasa sakit emosional. Metode ini secara klinis efektif dalam mengobati trauma, penyalahgunaan obat, panik, kecemasan, ketakutan, fobia, depresi ringan, dan gejala fisik yang berasal dari sumber-sumber emosional seperti sakit fisik, sakit kepala, kesulitan bernapas, tekanan darah tinggi dan banyak lagi (Steve, 2011). Terapi EFT ini terapi yang aman, praktis dan dapat dilakukan oleh individu. Pada terapi EFT terdapat urutan tapping yang dapat mengurangi emosi yang negatif (stress). Mekanismenya adalah sistem energi di dalam tubuh menjadi normal sehingga mampu menurunkan produksi hormon kortisol dan mampu mempengaruhi otak termasuk menurunkan produksi adrenalin sehingga epinefrin menurun. Oleh karena itu denyut jantung dan tekanan darah akan kembali normal.

Sedangkan ketukan ringan titik merdian pada titik organ dan jalur meridian Ki dapat meningkatkan hormon endrofin sehingga dapat menurunkan tekanan darah yang disebabkan oleh stres, dari pemaparan tersebutmaka tujuan penelitian ini adalah untuk mengetahui pengaruh terapi EFT terhadap penurunan tekanan darah. 


\section{METODE DAN BAHAN}

Penelitian ini menggunakan dua kelompok, kelompok intervensi yang mendapatkan terapi EFT selama 20 menit tiap hari selama tujuh hari dan kelompok kontrol yang menerima pendidikan kesehatan tentang manajemen hipertensi. Desain penelitian menggunakan quasi-experiment pretest-posttest with control group design. Sampel dalam penelitian ini untuk masing-masing kelompok berjumlah 16 responden. Teknik pengambilan sampel menggunakan consecutive sampling dengan kriteria inklusi (1) bersedia menjadi responden, (2) Tekanan Darah Sistolik (TDS) 140-160 mmHg dan Tekanan Darah Diastolik (TDD) 90-100 mmHg, (3) tidak menderita gagal ginjal, penyakit kardiovaskular lainnya dan diabetes, (4) pasien yang mengkonsumsi obat anti hipertensi, sedangkan kriteria eksklusi (1) pasien yang tidak mengikuti semua tahapan terapi, (2) menggunakan obat atau teknik untuk menurunkan stres, (3) mengalami penurunan kesadaran, (4) mempunyai masalah pendengaran. Penelitian ini dilakukan di wilayah kerja Puskesmas Purwokerto Utara II. Data dikumpulkan antara Oktober-Desember 2018. Alat untuk mengukur tekanan darah menggunakan Sphignomanometer air raksa manual dengan merk Syphmed Medical yang telah dikalibrasi oleh BMKG Banyumas.

Prosedur pengambilan data dimulai setelah mendapatkan perijinan dari Kesbangpolinmas, Dinas Kesehatan, Puskesmas Purwokerto Utara II. Peneliti melakukan skrining data penderita hipertensi yang diperoleh dari Puskesmas Purwokerto Utara II. kemudian memilah responden untuk dibagi ke dalam kelompok EFT dan kelompok kontrol secara acak dengan sistem kocokan. Setelah itu melakukan pengumpulan data dengan melakukan kunjungan rumah ke rumah responden. Setelah memperkenalkan diri dan menjelaskan tentang maksud, tujuan penelitian dan mendapatkan informed consent dari responden, langkah selajutnya adalah responden diukur tekanan darah pada hari pertama lalu diikuti dengan pelaksanaan EFT sampai hari ke tujuh, baru diukur tekanan darah posttest. Sedangkan pada kelompok kontrol, setelah pengambilan tekanan darah pretest, peneliti menjelaskan tentang manajemen hipertensi, lalu pada hari ke tujuh diukur kembali tekanan darahnya.

\section{HASIL DAN PEMBAHASAN}

Gambaran umum responden dapat dilihat dalam tabel berikut ini: 
Tabel 1. Karakteristik responden berdasarkan usia, Indeks Massa Tubuh (IMT), Tekanan Darah Sistolik (TDS), Tekanan Darah Diastolik(TDD) dan Jenis Kelamin

\begin{tabular}{llccc}
\hline No. Variabel & $\begin{array}{c}\text { Kelompok } \\
\text { Intervensi } \\
\text { mean } \pm \text { SD atau } \\
\mathrm{n}(\%)\end{array}$ & $\begin{array}{c}\text { Kelompok } \\
\text { Kontrol } \\
\text { mean } \pm \text { SD atau } \\
\mathrm{n}(\%)\end{array}$ & p value \\
\hline 1 & Usia & $63,18 \pm 6,94$ & $64,56 \pm 7,16$ & 0,786 \\
2 & IMT & $20,75 \pm 4,45$ & $20,45 \pm 4,15$ & 0,987 \\
3 & Pretest TDS & $159,93 \pm 15,68$ & $163,75 \pm 21,10$ & 0,567 \\
4 & Pretest TDD & $98,62 \pm 8,93$ & $93,00 \pm 12,03$ & 0,145 \\
5 & $\begin{array}{l}\text { Jenis } \\
\text { Kelamin }\end{array}$ & & & \\
& $\begin{array}{l}\text { Laki-laki } \\
\text { Perempuan }\end{array}$ & $2(6,6)$ & $2(6,6)$ & 1,000 \\
\hline
\end{tabular}

Dari tabel 1 dapat diketahui bahwa rerata usia pada kedua kelompok hampir sama (63, 18 tahun untuk kelompok intervensi dan 64, 56 tahun untuk kelompok kontrol). Hasil uji homogenitas untuk usia menunjukkan nilai $\mathrm{p}=0,786$. Hal ini bermakna tidak ada perbedaan yang bermakna usia antara kedua kelompok. Usia memang bukan satu-satunya faktor yang menyebabkan hipertensi, namun berdasarkan Riskesdas tahun (2018) menunjukkan bahwa kejadia hipertensi meningkat pada kelompok usia di atas 45 tahun. Tingginya angka kejadian hipertensi pada lansia disebabkan karena adanya kekakuan pembuluh darah dan penurunan kelenturan (compliance) arteri. Kekakuan pembuluh darah akan menyebabkan meningkatnya tekanan arteri. Proses degeneratif merupakan penyenab pasti dari tingginya risiko peningkatan tekanan darah pada usia lansia (Rosari, 2014). Hal ini juga diperkuat oleh pernyataan Huanhuan, et al., 2013 yang menyatakan kenaikan tekanan darah dapat dipengaruhi oleh usia seseorang, semakin usia bertambah maka akan terjadi perubahan fisiologis dalam tubuh, salah satunya adalah penebalan dinding arteri secara berangsur-angsur dapat menyebabkan penyempitan pembuluh darah.

Hasil penelitian menunjukkan bahwa IMT pada kedua kelompok berada pada rentang normal. Menurut Syahrini, Susanto \& Udiyono (2012) individu dengan obesitas menjadi salah satu faktor risiko terjadinya kenaikan tekanan darah.Mekanisme obesitas dalam meningkatkan tekanan darah belum diketahui secara pasti, namun beberapa penelitian telah membuktikan regulasi curah jantung dan sirkulasi darah penderita hipertensi dengan obesitas. Pada tubuh dengan obesitas terjadi penurunan tahanan perifer atau normal, sedangkan aktivitas saraf simpatis meninggi dengan aktivitas renin plasma yang rendah. Kondisi tersebut memicu peningkatan tekanan darah (Calles-Escandon, et al., 2016). 
Namun pada penelitian ini didapatkan IMT kedua kelompok dalam rentang normal dan tidak ada perbedaan yang bermakna IMT kedua kelompok $(p=0,987)$. Hal ini dapat disimpulkan bahwa IMT bukan merupakan faktor pengganggu dalam penelitian ini.

Hasil penelitian juga memperlihatkan bahwa responden perempuan lebih banyak dibandingkan laki-laki. Hal ini dapat diakibatkan oleh penurunan hormon estrogen. Kadar estrogen pada perempuan yang sudah mengalami menopause akan mengalami penurunan yang akan mengakibatkan kadar Low Devisity Lipoprotein (LDL) dalam tubuh yang menyebabkan peningkatan kadar kolestrol plasma, karena LDL mengandung $70 \%$ kolestrol plasma. LDL dapat teroksidasi yang akan bersifat merusak dinding vaskuler dan akan membentuk aterosklerosis yang berujung pada hipertensi (Aaronso \& Ward 2010). Selain itu dapat dikarenakan perempuan memiliki usia harapan hidup lebih tinggi dibandingkan dengan laki-laki. Berdasarkan penelitian yang dilakukan Rahmayanti \& Ariguntar (2017) menyatakan perempuan lebih cepat mencari bantuan kesehatan ketika mengalami masalah kesehatan dibandingkan laki-laki. Hal ini menjadi salah satu faktor usia harapan hidup perempuan lebih tinggi dibandingkan laki-laki (Robson, 2015). Baik tekanan darah sistolik maupun tekanan darah diastolik sebelum perlakuan antara kedua kelompok adalah homogen $(\mathrm{p}=0,567$; $\mathrm{p}=0,145)$, berurutan.

Tabel 2 Perbedaan Tekanan Darah Sistolik (TDS) dan Tekanan Darah Diastolik (TDS) sebelum dan sesudah perlakuan

\begin{tabular}{clll}
\hline Kelp & Variabel & Mean \pm SD & p value \\
Intervensi & TDS pre & $159,93 \pm 15,68$ & $<0,001$ \\
& TDS post & $152,18 \pm 13,81$ & \\
& TDD pre & $98,62 \pm 8,93$ & 0,699 \\
& TDD post & $97,98 \pm 9,66$ & \\
Kontrol & & & \\
& TDS pre & $163,75 \pm 21,11$ & 0,343 \\
& TDS post & $162,06 \pm 20,41$ & \\
& TDD pre & $93,00 \pm 12,03$ & 0,620 \\
& TDD post & $92,62 \pm 11,49$ & \\
\hline
\end{tabular}

Uji statistik yang digunakan untuk mengetahui perbedaan TDS dan TDD sebelum dan setelah perlakuan adalah uji paired t-test. Sebelum dilakukan uji tersebut, dilakukan uji normalitas terhadap data TDS maupun TDD untuk kedua kelompok. Uji normalitas yang digunakan adalah uji Shapiro-wilk. Hasil uji normalitas untuk data TDS pre, TDS post, TDD pre dan TDD post untuk kedua kelompok semuanya normal $(\mathrm{p}>0,05)$.

Pada tabel 2 diatas menunjukkan bahwa terdapat perbedaan yang bermakna TDS 
sebelum dan setelah pemberian EFT $(p<0,001)$, namun tidak ditemukan perbedaan yang bermakna TDD sebelum dan setelah perlakuan baik pada kelompok intervensi $(p=0,699)$, maupun pada kelompok kontrol $(\mathrm{p}=0,620)$. Demikian juga tidak ditemukan perbedaan yang bermakna TDS sebelum dan setelah perlakuan pada kelompok kontrol $(p=0,343)$.

Untuk mengetahui lebih lanjut pengaruh EFT dilanjutkan uji Independent T-Test, dengan membandingkan selisih tekanan darah antara kedua kelompok. Hal tersebut dapat dilihat pada tabel 3 berikut:

Tabel 3 Perbedaan Penurunan Tekanan Darah Sistolik (TDS) dan Tekanan Darah Diastolik (TDD) antara kedua kelompok

\begin{tabular}{lll}
\hline Variabel & Mean \pm SD & p value \\
$\Delta$ TDS Intervensi & $7,75 \pm 6,18$ & 0,014 \\
$\Delta$ TDS Kontrol & $1,69 \pm 6,89$ & \\
& & \\
$\Delta$ TDD Intervensi & $0,69 \pm 6,98$ & 0,582 \\
$\Delta$ TDD Kontrol & $0,50 \pm 4,89$ & \\
\hline
\end{tabular}

* $\Delta$ selisih tekanan darah pre dan post

Hasil penelitian menunjukkan ada perbedaan TDS sebelumdan sesudah EFT (p $<0,001)$. Analisis lebih lanjut menunjukkan bahwa terdapat perbedaan selisih penurunan TDS antara kedua kelompok. Dapat diartikan bahwa terapi EFT berpengaruh terhadap penurunan TDS pada lansia hipertensi. Terapi
EFT merupakan mind-body therapy. Teknik ini menggabungkan ketukan ringan (tapping) pada titik-titik meredian tubuh dan fase set up, yang dapat diartikan sebagai doa. Church(2009) menyebutkan bahwa berdoa adalah bagian dari beribadah, merupakan pengakuan bahwa seseorang bergantung pada satu-satunya Tuhan yang menciptakan manusia dan alam semesta. Dengan berdoa, timbul rasa aman dalam jiwa manusia, bahwa ada pendukung hidupnya yang amat dekat, yang tidak akan membuatnya sedih. Nilai ibadah sangat penting dalam mengurangi tekanan emosional sehingga berpengaruh pada proses terjadinya hipertensi. motivasi dan sikap beribadah yang ikhlas dapat dijadikan alternatif sebagai psikoterapi yang dapat menstabilkan hormon stres. Sedangkan menurut Shari et al. (2014), pada tahap set-up, merupakan pemberian sugesti pada diri sendiri. Adanya sugesti dalam bentuk kalimat afirmasi yang diucapkan oleh diri sendiri secara sadar, mengalir serta ikhlas dapat menetralkan pikiran negatif yang ada di dalam otak (Iskandar, 2010). Dengan adanya sugesti positif akan memengaruhi alam bawah sadar sehingga menciptakan ketenangan dan menghilangkan berbagai macam gangguan mental seperti tidak percaya diri, gugup, grogi, stres dan cemas. Selain itu, sugesti yang dibarengi tapping 
dapat menghilangkan psychological reversal pada seseorang yang mengalami masalah psikologis. Ketika psychological reversal pada seseorang hilang, maka orang tersebut akan merasa memiliki kehidupan yang bermakna, bahagia, dan merasa lebih nyaman (Rahmi, 2012).

Ketukan ringan pada EFT dilakukan di titik meridian Shao Yin Ki (Kidney) atau titik CB (Collar Bone). Terapi ketuk pada jalur meridian Ki bertujuan untuk memperbaiki atau mengoptimalkan fungsi ginjal. Perbaikan fungsi ginjal dikarenakan adanya rambatan energi dari jalur meridian akupunktur ke organ ginjal, hal ini dijelaskan dalam penelitian Putra (2016) yang meneliti menggunakan pendekatan biofisika dan biomolekuler. Penelitian Li (2011) mengeksplorasi dan mengidentifikasi komposisi protein dari ginjal tikus setelah dilakukan akupunktur di acupoint Taixi (Ki). titik Ki pada tikus menunjukan perubahan kinerja ginjal dalam meningkatkan NAD-dependent dehidrogenase isocitrate dan Quinon Reduktase di ginjal serta mendukung hubungan antara ginjal dan $\mathrm{Ki}$.

Selain meningkatkan fungsi ginjal terapi ketukan ringan juga dapat menurunkan tekanan darah melelui mekanisme pengeluaran hormon endorfin. Terapi ketuk dapat meningkatkan kadar endorfin dalam darah maupun sistemik. Endorfin memiliki fungsi yang besar didalam pengaturan respon terhadap stres (Ulfah, 2013). Saat tubuh akan mengaktifkan sistem simpatis dan korteks adrenal. Aktivasi pada sistem saraf simpatis akan menstimulasi medulla adrenal untuk melepaskan epinefrin dan norepinefrin. Sedangkan aktivasi pada korteks adrenal akan memengaruhi hipofisis untuk mensekresikan Adrenocorticotropin Hormon (ACTH) yang nantinya akan menstimulasi lapisan korteks adrenal sehingga terjadi pelepasan kortisol dalam tubuh. Adanya pelepasan hormon tersebut akan menyebabkan peningkatan frekuensi denyut jantung, pernapasan, tekanan darah, perubahan metabolisme tubuh dan kekakuan pada otot-otot tubuh. Saat tapping dilakukan, individu dalam keadaan relaksasi (Shari et al., 2014). Adanya relaksasi tersebut berdampak pada penurunan aktivitas saraf simpatis sehingga menyebabkan penurunan frekuensi napas, tekanan darah, dan denyut jantung. Kondisi relaks tersebut juga berpengaruh pada kondisi mental serta menurunkan kekakuan otot-otot tubuh. Hal itu terjadi karena adanya interaksi dari hormon psikoneuroendokrin yang dapat menurunkan 
produksi katekolamin, sehingga menimbulkan suasana nyaman dan menurunkan stress dan akhirnya akan menurunkan tekanan darah (Halm, 2009).

Pengetukan dalam EFT juga akan merespon jaringan saraf perifer sampai melibatkan saraf pusat. Ketika tapping saraf perifer akan mengirimkan stimulasi ke saraf pusat melalui neurotransmiter (Ningsih et al., 2015). Stimulasi tersebut akan bergerak melewati medulla spinalis menuju hipotalamus dan hipofisis sehingga menghasilkan efek terhadap sekresi $\beta$-endorfin, enkefalin dan serotonin yang berperan sebagai penghambat nyeri. Sekresi neurotransmiter ini juga berperan dalam perbaikan penyakit psikologis (psikiatrik). Adanya sekresi serotonin dan enkefalin di susunan saraf pusat dan plasma darah berperan terhadap terapi gangguan mood, depresi dan kecemasan (Purba, 2010).

Berbeda dengan TDS pada kelompok intervensi, TDD pada kelompok intervensi didapatkan hasil tidak ada perbedaan yang bermakna sebelum dan setelah EFT $(p=0,699)$. Analisis lebih lanjut menunjukkan bahwa tidak ada perbedaan selisih TDD antara kedua kelompok. Hal ini memberikan makna bahwa
EFT tidak efektif dalam menurunkan tekanan darah diastolik. Hal ini sejalan dengan hasil penelitian Suwardianto (2011) yang mendapati bahwa terapi relaksasi meditasi tidak dapat mempengaruhi penurunan tekanan darah diastolik terkait dengan sirkulasi koroner, jika ateri koroner mengalami arteriosklerosis

Arteriosklerosis atau pengapuran dinding pembuluh darah dapat mempengaruhi peningkatan darah diastolik (Jain, 2011). Arteriosklerosis akan menyebabkan penuruan elastisitas pembuluh darah. Hal ini dapat meningkatkan tahanan (resistensi) perifer, yang berdampak pada peningkatan tekanan darah.

Elastisitas vaskular dapat dipengaruhi oleh beberapa faktor yaitu usia, kolesterol, obesitas, diet tinggi lemak, merokok, olahraga dan konsumsi alkohol. Pada penelitian ini, tidak tergambarkan kadar kolesterol maupun diet responden. Sehingga tidak dapat diprediksi seberapa besar pengaruh tahanan perifer yang kaitannya dengan elastisitas vaskuler terhadap tekanan darah. Kemungkinan yang dapat ditegakkan adalah bahwa responden sudah mengalami arteriosklerosis dan penebalan dinding aorta. 
ISSN: 1858-3385, EISSN: 2549-7006

GASTER Vol. 17 No. 2 Agustus 2019

\section{KESIMPULAN DAN SARAN}

Penelitian ini menyimpulkan bahwa terapi EFT yang dilakukan setiap hari selama seminggu berturut-turut mampu menurunkan tekanan darah sistolik pada lansia hipertensi, namun terapi EFT ini tidak cukup efektif menurunkan tekanan darah diastolik.
Saran bagi lansia hipertensi untuk dapat menerapkan terapi EFT ini setiap saat, sedangkan untuk penelitian selanjutnya perlu dinvestigasi lebih lanjut tentang level stres maupun membandingkan penurunan tekanan darah setiap harinya.

\section{DAFTAR PUSTAKA}

Aaronso, P.I., \& Ward, J.P.T. (2010). Sistem kardovaskuler. Erlangga, Jakarta.

Badan Pusat Statistik. (2018). Statistik penduduk lanjut usia. Jakarta.

Calles-Escandon J, Ballor D, Harvey-Berino J, Ades P, Tracy R, Sobel B. (2016). Amelioration of the inhibition of fibrinolysis in elderly, obese subjects by moderate energy intake restriction. American Journal of Clinical Nutrition. 64: 7-11.

Church, D. (2009). The Treament of Combat Trauma In Veterans Using EFT (Emotional Freedom Techniques): A Pilot Protocol. Reprints and permission: http://www.sagepub. com/journalsPermissions.nav DOI: 10.1177/1534765609347549. 20(10):1-11.

Depkes R.I. (2013). Simposium dimensi baru penatalaksanaan hipertensi. Jakarta: Cermin Dunia Kedokteran.

Dinas Kesehtaan Kabupaten Banyumas. (2017).Profil kesehatan Kabupaten Banyumas Tahun 2017. Banyumas

Halm, M.A. (2009). Relaxation: a self-care healing of modality reduces harmful effect of anxiety, American Journal of Critical Care, 18(2).

Huanhuan, H., Gang, L., dan Takashi, A. (2013). Prevalence Rates of Self-Care Behaviors and Related Factors in a Rural Hypertension Population: a Questionnaire Survey. International Journal of Hypertension. http://dx.doi.org/10.1155/2013/526949 
Iskandar, E. (2010). The miracle of touch:panduan menerapkan keajaiban EFT (emotional freedom technique). Bandung: Qanita.

Jain, R. (2011). Pengobatan alternative untuk mengatasi Tekanan darah. Jakarta: Gramedia Pustaka Utama

Kemenkes R.I. (2014).Hipertensi. Jakarta: Pusat Data Informasi Kementrian Republik Indonesia.

Li, C.R. (2011). Effects of acupuncture at taixi acupoint (KI3) on kidney proteome. College of Acupuncture and Moxibustion, Liaoning University of Traditional Chinese Medicine, Shenyang 110847, PR China. American Journal of Chinese Medicine, 39 (4): 92-687

Ningsih, S.F., Karim, D., dan Sabrian, F. (2015). Efektivitas terapi emotional freedom technique (EFT) terhadap kecemasan pasien kanker payudara stadium II dan III. Journal of Medicine, $2(2)$.

Potter, P.A \& Perry A.G. (2012).Fundamental of Nursing. EGC: Jakarta.

Purba, J.S. (2010).Mekanisme kerja akupuntur dan aplikasi klinik. Departement Neurologi FK UI/ RSCM: Jakarta.

Putra, R.I. (2016). Pengaruh terapi Emotional Freedom Technique (EFT) terhadap skor kecemasan pada penderita hipertensi di Dusun Sengon, Desa Tanjunganom, Rakit, Banjarnegara, Skripsi, Universitas Jenderal Soedirman: Purwokerto.

Rahmayanti, S.N., dan Ariguntar, T. (2017). Karaktersitik responden dalam penggunaan jaminan kesehatan pada era BPJS di Puskesmas Cisoka Kabupaten Tangerang Januari-Agustus 2015.Jurnal Medicoeticolegal dan Manajemen Rumah Sakit, 6(1) : 61-65.

Rahmi, T. (2012). Efektivitas emotional freedom technique dalam mengatasi trauma gempa ibu rumah tangga. Jurnal Ilmiah Ilmu Pendidikan. Universitas Negeri Padang.

Riskesdas. (2018). Badan penelitian dan pengembangan kesehatan kementrian RI tahun 2018.

Rokade, P.B. (2011). Release of endomorphin hormone and its effects on our body and moods: A review. International conference on chemical, biological and environment sciences(ICCEBS'2011).

Rosari, F. (2014). Diagnosis and management of hypertension in the elderly patient. Lampung: UNLAM 
Seke, P.A., Bidjuni, H.J., Lolong, J. (2016). Hubungan kejadian stres dengan penyakit hipertensi pada lansia di balai penyantunan lanjut usia senjah cerah kecamatan mapanget kota Manado. E-journal Keperawatan, 4 (2): 1-5

Shari, W.W., Suryani., dan Emaliyawati, E. (2014).Emotional freedom techniques dan tingkat kecemasan pasien yang akan menjalani percutaneous coronary intervention, Jurnal Ilmiah Lontar: 2 (3).

Steve, B. (2011). An Introduction to Emotional Freedom Techniques (EFT). 3 rd Ed. Clifton Park NY : Thomson

Suwardianto, H. (2011). Pengaruh terapi relaksasi napas dalam (deep breathing) terhadap perubahan tekanan darah pada penderita hipertensi di puskesmas kota wilayah selatan kota kediri. Jurnal Stikes RS. Baptis, 4,1, 38-50.

Syahrini, E.N., Susanto, H.S., \& Udiyono, A. (2012). Faktor-Faktor Risiko Hipertensi Primer di Puskesmas Tlogosari Kulon Kota Semarang. Jurnal Kesehatan Masayarakat, 1(2).

Ulfah, E. (2013). Intervensi spiritual emotional freedom technique untuk menurunkan gangguan stres pasca trauma erupsi gunung merapi, Journal of Educational, Health and Community Psychology, 2(1).

Yaribeygi, H., Panahi, Y., Sahrei, H., Johnston, T.P., \& Sahebkar, A. (2017). The impact stress on body function: A review. Experimental and Clinical studies Journal; 16: 1057-1072, doi: 10.17179/excli2017-480 